\title{
Waqf Land Disputes and Alternative Settlements
}

DOI: https://doi.org/10.47175/rissj.v2i3.247

\section{| Faisal |}

Faculty of Law, Universitas Muhammadiyah Sumatera Utara, Indonesia

faisal@umsu.ac.id

\begin{abstract}
The system of Waqf management is still not as expected because many land dispute problems that arise in the midst of society are caused by factors that hinder the delivery of Waqf intentions from a representative. The issue of Waqf disputes is often brought to the path of litigation (court) so that alternative channels are needed in finding a resolution. The research method used is the method of juridical law research normative with the approach of legislation. The purpose of this research is to prioritize nonlitigation pathways first to resolve Waqf disputes. The results showed that the factors that cause the non-implementation of Waqf lies in administrative problems when trying to make a deed of Waqf land pledge caused by disapproval by the heirs of the representative to the management of Waqf by nadzir who lack integrity and responsiveness. Recommendations on the issue, Waqf disputes should first put forward a non-Litigation line, because the Litigation line as a last resort to find a place to resolve land disputes. KEYWORDS

waqf; heir; administrative; non-litigation
\end{abstract}

\section{INTRODUCTION}

Waqf disputes become complex problems from time to time. Various alternative solutions need to be reviewed in relation to the efficiency of Waqf dispute resolution in order to be addressed and minimized so that land problems can be solved by analyzing juridical aspects and various solutions.

Furthermore, Waqf (land) property in principle belongs to the people. Thus, the benefits must also be felt by the people. So ideally Waqf property is a collective responsibility, in order to maintain its existence. Thus, the existence of institutions that manage Waqf property, is absolutely necessary as has been done by some Islamic countries. Indonesia still seems slow in managing Waqf, even though the majority of the population is Muslim, and ranks first in the world's Muslim population. The implications of this inaction, causing the number of Waqf assets are less manageable and even some are still untapped.

A Dispute land is in the community arises when there are parties who feel harmed by other parties. When the party that feels aggrieved conveys its dissatisfaction to the other party and the other party does not show dissent, then there is a dispute or dispute. Basically dispute resolution (including Waqf land disputes) can be done in two ways; non-litigation and litigation.

With the development of the times, there are various disputes concerning Waqf property. Especially in land Waqf which in ancient times was not clear administration nor documentation 4. So here the writing team tries to trace the example of Waqf dispute cases and the settlement process in Indonesia both from the path of litigation and non-litigation based on the prevailing laws and regulations. Through this research, it can be known the main cause of Waqf dispute so that the public can avoid it, as well as a source of reference for the community involved in the case of Waqf disputes in the future. The main cause of 
Waqf property disputes is administrative problems. Especially in land matters that currently require a wide variety of authentic proof of ownership. This conclusion is similar to 15 researches that mention that Waqf land that does not meet administrative provisions creates legal uncertainty over the status of the land. Dispute resolution through alternative channels is much more efficient and effective. Therefore, a lawsuit should only be filed if there is no other way to resolve the dispute (Muhammad Rifqi Hidayat \&Parman Komarudin, 1981). According to Zainuddin, If we need to control arrive by the state must be based on three standards of lawful destinations, to be specific covering lawful certainty, equity and advantage. When this objective is accomplished, it can be discovered that the proper to control arrive by the state will be able to attain its genuine points and destinations, to be specific the most prominent conceivable thriving for the individuals (Zainuddin, 2020) .

In general, there are several kinds of problems of a land dispute, among others: (Urip Santoso, 2005).

1. Issues concerning priorities can be determined as the rightful holder of land that has the status of rights or on land that has no rights.

2. A rebuttal to a right reason or Verification of procurement is utilized as the establishment for granting rights.

3. Errors/errors in granting rights due to the application of insufficient or incorrect regulations.

Disputes or other difficulties with societal implications.

The problem of land, viewed in a juridical way is not a simple solution. The occurrence of legal disputes about land, is derived from a one-party complaint (person / entity) containing objections and claims for land rights either to the status of the land or the priority of ownership in the hope of obtaining an administrative settlement in accordance with the provisions of the applicable regulations.

The main thing that often causes problems in practice is the number of Waqf land that is not followed up by the creation of Waqf pledge deed. The implementation of Waqf that occurs in Indonesia is still done religiously or based on mutual trust. This condition, in the end makes the land that is endowment has no legal basis, so that if in the future there are problems regarding the ownership of Waqf land settlement will encounter difficulties, especially in terms of proof. Another thing that often causes problems in Waqf practice in Indonesia is the request for the return of Waqf land by wakif heirs and Waqf land controlled hereditary by Nadzir whose use deviates from Waqf agreement. In practice it is often heard and seen the existence of Waqf land requested again by the wakif heirs after the wakif died. This condition is basically not a serious problem, because when referring to the provisions of the legislation, Waqf can be done for a certain time, so that when the specified time has been exceeded, the Waqf is returned to the wakif heirs. But especially for land Waqf, the provisions of the making of Waqf pledge deed has abolished the ownership of the rights to the land that is endowment so that the land that is endowment cannot be requested again.

\section{RESEARCH METHODS}

Research methods used are normative juridical research. Soerjono Soekanto stated that there are 5 scopes of lawful consider, specifically lawful concepts, lawful frameworks, lawful synchronization measures, lawful history, and lawful comparisons (Soerjono Soekanto, 2012). For this research, used statute approach. 


\section{RESULTS AND DISCUSSION}

Waqf which means "withholding" is to withhold the property taken advantage of which the property is not destroyed instantly, and its use for things that are allowed shari'a (Islamic law) to obtain pleasure from Allah (M. Daud Ali, 1988). By releasing the Waqf property, wakif has legally lost his ownership rights so that he no longer has the authority or right to use it for personal gain and the right to transfer his ownership to another party, such as selling, giving including bequeathing to the heir (M. Daud Ali, 1988).

The meaning of withholding property in the context of Waqf can be interpreted eternally or temporarily, from all forms of personal actions, such as selling and giving Waqf or others, for the purpose of its use or its results repeatedly for the general public or special interest, as defined by the purposes required by the wakif and within the limitations of sharia law (Mundzir Qahaf, 2005).

Waqf is a separate legal action that is viewed from a certain angle is duplicate, because on the one hand the act causes the object to gain a special position, while on the other hand the act gives rise to a legal entity in customary law that can participate in legal life as a legal subject (Abdurrahman, 1994).

If we read contextually in the Qur'an, in general there is no verse of the Qur'an that explains the concept of Waqf clearly. But based on the opinion of the scholars that the Waqf includes infaq fi sabilillah, then The academics' explanation of the notion of Waqf is based on the generality of verses of the Quran that explains about infaq fi sabilillah.

The Word of Allah in Surah Al Imran verse 92 which means; "You will not at least reach the right end until you have spent all of your money on what you enjoy, Allah knows it." Then, Surah Al-Haj verse 77, which means; "Do good deeds, that you may be victorious." Furthermore, in Surah al-Baqarah verse 267 is stated as follows; O you who have faith! And do not choose the evil from it, lest you should take it away, and do not take it with your eyes. Know that Allah is All-Rich, All-Laudable. Furthermore, Surah alBaqarah verse 261; "Allah increases for whom He pleases, and Allah is All-Embracing and All-Knowing.". The words of giving away the wealth mentioned in Qur'an are not less than 72 places, in addition to conflicting on obligatory expenses, such as zakat or providing for the family, also pointing to Sunnah law, such as grants, Waqf, and others. In addition, Allah SWT promises to those who spend some of their wealth, multiplied the reward 700 times (Ahmad Rofiq, 2003). Explicitly in the Qur'an there is no evidence of Waqf. In these verses there is a suggestion to do infaq in general against some of what a person has, and included in the general sense of infaq according to the number of scholars is through the means of Waqf (Syamsul Anwar, 2007).

Hadith also regulates Waqf, the majority of scholars stated the origin of Waqf worship in Islam is the period of the Prophet Muhammad SAW, at which time Umar bin Khattab obtained a plot of land in Khaibar, then he came to the Prophet SAW to ask for his instructions on the land, he said; O Messenger of Allah, I have obtained a plot of land in Khaibar which I have never gotten more profitable than it. What is your command concerning the treasure." The Messenger of Allah (peace and blessings of Allah If you wish, you can withhold the basic (institutionalizing of the object) and give away its benefit (Ibn Umar) further reporting; then Umar gave the land with the provision that it should not be sold, given or inherited. Ibn 'Umar said: 'Umar gave it to the poor, relatives, slaves, sabilillah, ibn sabil, and guests. It is not forbidden for him who owns the Waqf to eat in a good manner or to eat with no intention of accumulating wealth. Bukhori). Another hadith that explains Waqf is the hadith described by the Muslim Imam of Abu Hurayrah. The Nash hadith is; "On the off chance that a man kicks the bucket, his deeds are cut off but from three sources, to be specific aid jariah (Waqf), information that can be profited, and a 
righteous child who prays for it."

Ijma', that the clerics agreed (ijma') to acknowledge Waqf as a jariyah charity that's endorsed in Islam. No one can deny and dismiss the hone of Waqf in Islam since it has ended up a hone that has continuously been practiced and practiced by the companions of the prophet and the Muslims since the starting of Islam until presently.

Ijtihad, The detailed provisions on Waqf are based on the ijtihad of islamic jurists, among others; Imam Al Zuhri's opinion, that donating dinar law may, by making the dinar as business capital, then the profit is channeled to mauqul alaih. MUI Fatwa on Waqf of Money year 2002. Law No. 41 of 2004 on Clairvoyance.

Regulations on Waqf in Indonesia have existed since the time of the Dutch East Indies until the time of independence. But administratively only started in 1905 with the registration of Waqf land based on various circulars. Some arrangements about Waqf in Indonesia:

a. Law No. 41 of 2004 on Waqf.

b. Government Regulation No. 42 of 2006 Concerning the Implementation of Waqf Law No. 41 of 2004

c. Regulation of the Minister of Religious Affairs No. 73 of 2013 concerning Procedures for The Regulation of Immovable Objects and Moving Objects Other than Money.

d. Regulation of the Minister of Religious Affairs No. 4 of 2009 concerning The Administration of Waqf Money Registration.

e. Regulation of the Indonesian Waqf Agency Number 1 year 2008 concerning Procedures for Drafting Recommendations on The Application for Redemption / Change of Status of Waqf Property.

f. Regulation of the Indonesian Waqf Agency Number 3 of 2008 concerning Procedures for Registration and Replacement of Nazhir Property Waqf Immovable in the Form of Land.

g. Control of the Indonesian Waqf Office Number 1 of 2009 concerning Rules for The Administration and Advancement of Waqf Property within the Frame of Cash..

h. Regulation of the Indonesian Waqf Agency Number 2 of 2012 concerning Representatives of the Indonesian Waqf Agency.

$i$. Compilation of Islamic Law Book III Law of Self-Waqf.

j. Government Regulation No. 28 of 1977 concerning The Regulation of Owned Land

k. Regulation of the Minister of Home Affairs No. 6 of 1977 concerning Land Registration System on Land Owned

1. Regulation of the Minister of Religious Affairs No. 1 of 1978 concerning Regulation on the Implementation of PP. No. 28 Year 1977 on The Endowment of Property.

m. Regulation of the Director General of Islamic Community Guidance No. Kep/D/75/1978 concerning Forms and Guidelines for implementation of regulations on The Destruction of Owned Land

n. Decree of the Minister of Religious Affairs No. 73 of 1978 concerning Designation of specialist to the Head of Territorial Office of the Common Service of Devout Undertakings/ level all through Indonesia to name / reject each head of the Locale Kua as the Official of Waqf Pledge Deed

The definition of Waqf based on Indonesia's positive laws can be seen in:

a. Article 1 Point (1) Law No. 41 of 2004 concerning Waqf (Waqf Law), declared Waqf is as a legalaction suwakif to isolated and / or hand over a few of his property to be utilized until the end of time or a certain period of time in agreement with his interface for the purposes of revere and / or common welfare agreeing to shari'ah. 
b. Article 1 number (1) Government Direction No. 42 of 2006 concerning the Execution of Law No. 41 of 2004 on Waqf, The definition of Waqf is the act of a individual or a bunch of individuals (wakif) to isolated and / or donate up a few of his property to be utilized until the end of time or for a certain period of time in understanding with his interface for the purposes of adore and / or common welfare agreeing to shari'ah. c. Compilation of Islamic Law (KHI) as expressed in Article 215 section (1), it is expressed that Waqf is the lawful act of a individual or bunch of individuals or lawful substances that isolates portion of his property and institutionalizes it for the purposes of revere or other open purposes in understanding with Islamic teachings.

Based on the definition of Waqf as described above, the function of Waqf if it refers to the provisions of Article 5 of Waqf Law, is to realize the potential and economic benefits. In addition, Waqf property is used for the purposes of worship and to promote the general welfare. Furthermore, Waqf function is divided into four, namely: (Muhammad Abid Abdullahal Kabisi, 2004).

a. Economic Functions; One of the most important aspects of Waqf is the state as an effective wealth transfer system.

b. Social Functions; If Waqf is managed and implemented properly, various shortcomings of facilities in the community will be more easily resolved.

c. Function of Worship; Waqf is a part of worship in the implementation of The command of Allah SWT, as well as in strengthening the relationship with Him.

d. Akhlaq function; Waqf will foster a good attitude, where everyone is willing to sacrifice what he loves most for a higher purpose than his personal interests.

Therefore, before the birth of Law No. 4 of 2004 on Waqf, the rules on Waqf are still spread in rules that are partial and the level is under the Law. But after the birth of the Waqf Law in 2004, all rules governing the Waqf must refer to the provisions of the Waqf Law, because this law already regulates comprehensively.

Dispute which has meaning as a process of interaction between two or more individuals or bunches who each battle for its interface or the same protest, to be specific arrive and other objects related to the soil such as water, plants, mines and discuss that are on the arrive in question." (Urip Santoso, 2005).

Based on the explanation above, then land conflict is not new. However, the dimension of conflict is more widespread in the present, when compared to colonial times. Some of the causes of land conflicts are: (Adrian Sutedi, 2009).

a. Unbalanced and uneven landownership / possession.

b. Mismatch of agricultural land use and non-agricultural land

c. Lack of impartiality to the people of the weak economic class

d. Lack of acknowledgment of innate peoples' rights to arrive (ulayat rights)

e. The weak bargaining position of the people who hold land rights in land acquisition.

Furthermore, regarding the control of Waqf land by Nadzir for generations and its use that is not in accordance with the Waqf pledge, this is attributed to the lack of supervision from the relevant agencies. The heirs or descendants of Nadzir assumed that the land belonged to Nadzir so that its use was free according to their own interests. This was due to the ignorance of Nadzir's heirs.

Some of the things that cause Waqf disputes include;

1. There are still many Waqf land that is not followed up with the creation of Waqf pledge deed. The implementation of Waqf that occurs in Indonesia is still done religiously or based on mutual trust. This condition, in the end makes the land that is endowment has no legal basis, so that if in the future there are problems regarding 
the ownership of Waqf land settlement will encounter difficulties, especially in terms of proof.

2. The request for the return of Waqf land by the wakif heirs and Waqf land is controlled for generations by Nadzir whose use deviates from the Waqf agreement. In practice it is often heard and seen the existence of Waqf land requested again by the wakif heirs after the wakif died. This condition is basically not a serious problem, because when referring to the provisions of the legislation, Waqf can be done for a certain time, so that when the specified time has been exceeded, the Waqf is returned to the wakif heirs. But especially for land Waqf, the provisions of the making of the Waqf pledge deed has abolished the ownership of the rights to the land that is endowment so that the land that is endowment cannot be requested again.

3. The control of Waqf land by Nadzir hereditary and its use is not in accordance with the Waqf pledge, this is attributed to the lack of supervision from the relevant agencies. The heirs or descendants of Nadzir assumed that the land belonged to Nadzir so that its use was free according to their own interests. This was due to the ignorance of Nadzir's heirs.

4. Waqf practices implemented in Indonesia are still implemented conventionally that allows vulnerable to various problems and not a few that end up in court (Suhrawardi K. Lubis, 2010).

5. There are irregularities against Waqf objects carried out by irresponsible persons (Suhrawardi K. Lubis, 2010).

6. It has become a common secret there are Waqf objects that are traded (Suhrawardi K. Lubis, 2010)

In addition to this, Waqf disputes can also occur due to several possibilities, namely asfollows: (Suhrawardi K. Lubis, 2010)

1. The shallowness of some Muslims' understanding of the position and meaning of Waqf property, both for wakif and society, while Waqf has two dimensions; worship and social.

2. Soaring land prices can be a trigger for Waqf problems.

3. When making the Waqf pledge, the wakif does not take into account the economic condition of the heirs to be left behind, so that all of his property or most of it is endowment. As a result, there was denial by his heirs.

4. The economic condition of the nadzir party is not favorable, thus encouraging him to misuse Waqf property.

5. Nadzir condition that does not understand that the use of Waqf property must be in accordance with the purpose of the wakif.

6. The waqf party does not expressly inform the child or his heirs that certain land has been declared to a particular party.

7. Nadzir is not a legal entity, but rather a personal one, so it is more free and willing and empowers the use of Waqf objects without control.

Based on the portrayal over, it can be caught on that the reason or cause of the Waqf dispute is the unfulfilled arrangement of Waqf land that occurs in Indonesia in Law No. 41 of 2004, there are still many Waqf land that is not followed up with the making of Waqf pledge deed, the request for the return of Waqf land by wakif heirs and Waqf land controlled hereditary by Nadzir.

If referring to the definition of Waqf as formulated in Article 1 point 1 of Law No. 41 of 2004 concerning Waqf, not in detail regulate the object of Waqf is the land field. In addition, although in therealm ofIslamic fiqh can actually include various objects, but in various 
histories / hadiths more tell the problem of Waqf is about the land, but various scholars understand that Waqf is not a land-can be, as long as the object is not immediately destroyed / exhausted when taken advantage of.

The affirmation of ijtima' of the scholars on the object of Waqf is poured in the Waqf Law contained in Article 16, which states that Waqf property consists of moving objects, and immovable objects. Thus Law No. 41 of 2004, does not limit that Waqf is only intended for land only, but also moving objects. But in practice in Indonesia, generally when talking about Waqf, it will be associated with land. Regulation on otanah as an object of Waqf is technically regulated in Government Regulation (PP) No. 28 of 1977 concerning The Destruction of Owned Land.

In the implementation of Waqf, administrative provisions in Government Regulation No. 28 of 1977 concerning The Endowment of Property, Presidential Instruction No. 1 of 1991 on Compilation of Hu kum Islam, especially Book III governing The Law of Waqf and Law No. 41 of 2004 on Waqf has not fully received perha tian society in general, and especially the parties who are waqf. In the self wakif that stands out is the religious side of Waqf practice. Therefore, wakif does not feel the need to be recorded or administrated. Thus, theWaqf is done on the basis of sincerity and discipleship alone and according to local customary ordinances without the support of authentic data and affidavits, so that juridically ad mi nistratif Waqf status is much unclear. The methods taken to resolve the dispute according to S. Roberts in Kriekhoff are: a) the use of violence, i.e. directly between personality ; b) through ceremonies or rites, e.g. traditional ceremonies; c) humiliate, e.g. by satire/allusions; d) through supernatural beings, e.g. by magic; e) excommunication; f) through talks, which may consist of: 1) direct talks (negotiations); 2) indirect speech or with the help of third parties, either acting as intermediaries or advisors (mediation / mediators or intermediaries / go between) or as parties to resolve (arbitration / arbitration and judiciary / adjudication) (Fadhilah, 2011).

Elements that must be present during implementation of Waqf registration of property rights, namely: First, Wakif. The party that Waqf the land is called wakif. According to Article 1 paragraph (2) of Government Regulation No. 28 of 1977, wakif is a person or persons or legal entity who owns his property, while according to Article 1 number 2 of Law No. 41 of 2004, wakif is the party that owns his property. Wakif can be a person per person either individually or together with others, or a legal entity that qualifies as the subject of Property Rights. Thus, foreigners domiciled in Indonesia and legal entities that are not the subject of Property cannot be located as wakif. The requirement to become a wakif is stipulated in Article 8 of Law Number 41 of 2004, namely: Wakif Individual and Wakif Legal Entity. Wakif individuals can only do Waqf if they meet the requirements, namely: adult; be sized; not be prevented from doing legal acts, and; landowner. Wakif legal entities can only do Waqf if they meet the requirements as the subject of property rights. A person or legal entity who owns property must voluntarily, sincerely, and willfully own the property, there must be no pressure, coercion, intimidation from the other party. Second, Nadzir. According to Article 1 paragraph (4) of Government Regulation No. 28 of 1977, A nadzir is a group of persons or legal organizations tasked with the upkeep and administration of Waqf objects. According to Article 1 number 4 of Law No. 41 of 2004, The nazhir is the party who gets Waqf property to administer and develop in line with its terms. Third, the Land of The Endowment. Because in the Waqf of land there is an act of land surrender forever, then the land that can be endowment only land that has the status of Property because the property of property rights is hereditary, meaning that the land has no time limit. Land Use Rights, Building Rights, Usage Rights, and Rental Rights For 
Buildings can not be endowment because it has a certain time limit. If the Right to Business, Right to Use Buildings, Right to Use, or Rental Rights For Buildings want to be endowment, then the right to land is changed first to Property Rights. Third, the Land of The Endowment. Because in the Waqf of land there is an act of land surrender for ever, then the land that can be endowment only land that has the status of Property because the property of property rights is hereditary, meaning that the land has no time limit. Land Use Rights, Building Rights, Usage Rights, and Rental Rights For Buildings can not be endowment because it has a certain time limit. If the Right to Business, Right to Use Buildings, Right to Use, or Rental Rights For Buildings want to make waqf then the right to land is changed first to Property Rights (Santoso, 2014).

The development of land-owned clairvoyance institutions, which developed in Indonesia, inspired the makers / designers of the UUPA where one of the articles in the LAW, which regulates specifically on The Endowment of Property, namely Article 49 which reads as follows:

(1) Land ownership rights of religious objects and sosial,as long as used for business in the field of religion, and socially recognized and protected.

(2) These groups are also assured of obtaining sufficient land for religious and social structures and enterprises as referred to in Article 14 can be given land controlled directly by the state with the right to use.

(3) The property is protected, and regulated by a Government Regulation.

Referring to the provisions contained in Article 49 of the above. Thus, this is a formal juridical recognition of the existence of state-owned land so that it has been aligned with the rights contained in other LAWS, such as Property Rights, Business Rights, Building Rights and Usage Rights. Nevertheless, the order of paragraph (3) of Article 49 was answered after the enactment of the Law for approximately 17 years, when after in 1977 the government issued Government Regulation No. 28 of 1977 concerning The Regulation of Owned Land.

The use of Waqf land is as the function of Waqf in general, namely for the benefit of the people, but specifically Law No. 41 of 2004 on Waqf stipulates that the allocation of Waqf land is dependent on Waqf pledge made. Waqf pledge is a valid pronunciation that is spoken sincerely to give up his property that will be used in the way of Allah. Therefore, the party that will make use of the land must supplement with letters relating to the land.

It is stipulated in Article 9 paragraph (5) of Government Regulation No. 28 of 1977, which is as follows:

In carrying out the pledge as referred to in paragraph (1), the party who owns the land is required to bring and submit to the official the following letters: (a) certificate of property rights or other proof of land ownership, (b) a certificate from the head of the village reinforced by the head of the local sub-district explaining the truth of land ownership and not getting caught in a case, (c) a certificate of land registration, (d) permission from the regent / mayor of the regional head c.q. Head of subdirectory agararia local.

As a technical rule to follow up PP No. 28 of 1977 which has been issued by the Regulation of the Minister of Home Affairs No. 6 of 1977 which regulates the procedure of registration of property rights that contains among others the requirements of the land that is endowment, officials of Waqf pledge deed, registration process, registration fee, and transitional provisions. Furthermore, The Minister of Religious Affairs Regulation No. 1 of 1978 details more about the procedures of Waqf of property, among others, about Waqf pledges and deed, officials of Waqf pledge deed, rights and obligations of nażir, changes in the perWaqf of property, supervision and guidance, settlement of Waqf land disputes, and the cost of Waqf land. In the event of a property or civil rights dispute 
When considering the provisions of Article 9 paragraph (5), Government Regulation No. 28 of 1977 and its explanation above, it is implied that the Waqf Pledge Deed is an authentic deed that can be used in the resolution of disputes that may arise in the future, concerning the land that is Waqf. In other words, the Waqf Pledge Act is a proof of the implementation of Waqf as well as explaining the status of Waqf land.

Alternative settlement of Waqf land disputes can be pursued in several ways. The first way that can be taken in resolving dispute Waqf land is through non-litigation means that are informal ways based on the assention of the parties to the debate through the choice of settlement channels such as:

1. Negotiation; that is, a process of bargaining by negotiating peacefully to reach an agreement between litigants, without involving a third party as an intermediary.

2. Mediation; Dispute resolution process between disputed parties involving third parties (mediators) as advisors.

3. Conciliation; Conciliation is an attempt to bring together the wishes of the disputing parties to reach a settlement by involving a third party (conciliator). In resolving disputes, conciliators have the right to express their opinions publicly without favoring anyone. The Conciliator shall not have the right to make a final decision in the dispute for and on behalf of the parties as it is taken solely by the parties to the dispute.

4. Arbitration; It is a means of settling respectful debate exterior the common court based on a composed assertion assention by the dissinger. An discretion assention is an assention within the frame of an intervention clause contained in a composed assention made by the parties some time recently or after a debate emerges.

The second way is a litigation settlement is done by taking legal action at the bada judiciary. The judiciary is part of the judicial power in Indonesia which is shaded by the Supreme Court consisting of the general judicial environment, the religious judicial environment, the military judicial environment, the state administrative judicial environment, and by a Constitutional Court.

Settlement of Waqf land disputes through litigation channels is one of the authority of the Religious Judiciary. Another affirmation related to the authority is also outlined in Article 50 UURI No. 3 of 2006 concerning Amendments to Law No. 7 of 1989 concerning Religious Justice stated that;

(1) In the event of a property dispute or other dispute in the case as referred to in Article 49 , the specific object of the dispute must be decided first by the court within the General Judiciary.

(2) In the event of a property dispute as referred to in paragraph (1) which is the subject of the law between people who are Muslims, the object of the dispute is decided by a religious court together with the case as referred to in Article 49.

The affirmation of the settlement of Waqf land disputes is written in Article 62 of the Waqf Law which states that: "(1) Settlement of disputes is taken through deliberation for consensus. If the dispute resolution as defined in paragraph (1) is unsuccessful the dispute may be resolved through mediation, arbitration, or the court". Referring to Article 62 of the Waqf Law, basically the resolution of the dispute must first be taken through deliberation for consensus. If the resolution of the dispute through deliberation is If litigation is unsuccessful, the disagreement may be settled through mediation or arbitration, or court.

In the event that mediation does not succeed in resolving the dispute, the dispute may be brought to a sharia arbitration body. If a sharia arbitration body is unable to resolve the issue, 
it may be referred to the Religious Court and/or the Supreme Court. sharia court. As for the technical and procedures of filing a lawsuit to the Religious Court and/ or sharia court, conducted according to the applicable provisions.

\section{CONCLUSION AND RECOMMENDATION}

Waqf disputes occur because the number of Waqf land that is done is not followed up by the creation of Waqf pledge deed, as evidence of the transfer of management and ownership rights, the denial of the implementation of Waqf by waris wakif experts, by requesting the return of land that has been made waqf by wakif. The control of Waqf land by nadzir hereditary and its use is not in accordance with the Waqf pledge, Waqf practices implemented are still implemented conventionally that allows vulnerable to various problems and not a few that end up in court. There are irregularities in Waqf objects carried out by irresponsible persons. The need for legal awareness for wakif heirs to carry out the making of Waqf pledge deed. In addition, the integrity of the person in order to have the responsibility to manage Waqf. For settlement of Waqf Land Disputes can be done on a non-litigation and litigation basis.

\section{REFERENCES}

Abdurrahman. (1994). The Problem of Land Owned and Position of Waqf Land in Our Country, Citra Aditya Bakti, Bandung.

Adrian Sutedi. (2009). Transfer of Land Rights and Registration, Jakarta: Sinar Grafika Publisher.

Ahmad Rofiq.(2003). Islamic Law in Indonesia. Jakarta: PT Raja Grafindo Persada.

Indonesian Waqf Agency, http://bwi.or.id/index.php/in/pengertian-waqf-tentang-waqf-54.

Fadhilah, N. (2011). Waqf Land Dispute And Its Settlement Strategy. Journal de Jure, 3(1), 71-85. https://doi.org/10.18860/j-fsh.v3i1.1321

M. Daud Ali. (1988). Islamic Economic System, Zakat and Waqf, Jakarta: UI Press.

Mundzir Qahaf. (2005). Productive Waqf Management, Jakarta: Khalifa.

Muhammad Abid Abdullah al Kabisi. (2004). Waqf Law, Jakarta: IIMAaN Press.

Muhammad Rifqi Hidayat, \& Parman Komarudin. (1981). Settlement of Waqf Disputes Through Litigation and Non-Litigation, 53(9), 1689-1699.

Maria, SW Sumardjono. (2009). Mediation of Land Disputes, Jakarta: Kompas Book Publisher.

Onny Medaline. (2016). "Waqf of Ulayat Kaum Land in West Sumatra" BWI Journal. Edition (2).

Santoso, U. (2014). Legal Certainty of Waqf of Property. Perspective.19(2), 71. https://doi.org/10.30742/perspektif.v19i2.10

Suhrawardi K. Lubis. (2010), Waqf and Empowerment of People. Jakarta: Sinar Grafika.

Syamsul Anwar, (2007), Study of Contemporary Islamic Law, Jakarta: RM. Books.

Urip Santoso. (2005). Agrarian Law and Land Rights, Jakarta: Prenada Media.

Law of the Republic of Indonesia Number 48 of 2009 concerning the Fundamentals of Judicial Power.

Law of the Republic of Indonesia Number 3 of 2006 concerning Amendments to Law No. 7 of 1989 concerning Religious Justice.

Zainuddin, Z. (2021). Right to Own Land by the State in the Frame of Constitutional Law. Randwick International of Social Science Journal, 2(2), 46-57. https://doi.org/10.47175/rissj.v2i2.214 